$8^{\text {th }}$ International Scientific Conference "Business and Management 2014" May 15-16, 2014, Vilnius, LITHUANIA Section: International Economy: Problems of Innovation and Marketing Management http://www.bm.vgtu.lt
ISSN print 2029-4441 / ISSN online 2029-929X

ISBN print 978-609-457-650-8 / ISBN online 978-609-457-649-2

Article number: bm.2014.048

http://dx.doi.org/10.3846/bm.2014.048

(C) Vilnius Gediminas Technical University, 2014

\title{
INTERNATIONALIZATION PROCESSES AND EFFECTIVE PRACTICES OF HRM: EMPLOYEE PERFORMANCE AND COMMITMENT IN LATVIA AND LITHUANIA
}

\author{
Liudmila Lobanova ${ }^{1}$, Iveta Ozolina-Ozola ${ }^{2}$ \\ ${ }^{1}$ Vilnius Gediminas Technical University, Faculty of Business Management, \\ Sauletekio al. 11, LT-10223 Vilnius, Lithuania \\ Email: liudmila.lobanova@vgtu.lt \\ ${ }^{2}$ Riga Technical University, Faculty of Engineering Economics and Management, \\ Kalnciema St. 6, LV-1048 Riga, Latvia \\ Email: iveta.ozolina-ozola@rtu.lv
}

\begin{abstract}
Human resource management consists of various practices, and, time passing on, many new practices emerge. There is small amount of scientific studies explored the effective human resource management practices, its combinations and the selection criteria for specific situation to facilitate employee commitment and performance under the condition of internationalization processes. Also of having scientific value, the findings on this scope could contribute to practical problem solving in organisations. The purpose of this research is to identify the human resource management practices that are effective for employee commitment and performance, using case study of human resource management practices in Latvia and Lithuania.
\end{abstract}

Keywords: human resource management practice, employee performance, commitment.

JEL classification: A13, E24, F02, M12, M14, M51.

\section{Introduction}

The importance of the development of human resource management (HRM) practices in nowadays is associated with attention to such priorities as improving of staff engagement, because this tends to lead to employee performance and commitment, reduces staff turnover and improves the well-being of employees (Witemeyer 2013; Becker, Cropanzano 2011; Hakanen et al. 2008; Toh et al. 2008; Wright et al. 2007; Michie, West 2004; Wright, Cropanzano 2000). According Randall S. Schuler (2000), as we entered in the new millennium, the environment becomes more global, managing people also becomes more challenging, more unpredictable and uncertain and more subject to rapid change and surprise. Today forces of global competition, worldwide labor availability, business ethics, and the environment are winning the attention of HRM (Schuler 2000).

At the present stage of internationalization and eurointegration proceses the priorities of HRM practices development is more often associated with special attention to such areas as research and innovation (by creating new products/services that generate growth and jobs and help address social challenges), raising Europe's employment rate (by creating more and better jobs) and modernising labour markets and welfare systems (Lobanova, Ozolina-Ozola 2013). Under those conditions, it is clear that the statement of the targets and formulation of slogans, as well as drastic consolidation of finances are not sufficient for solving the problem, which is much more complicated than it may seem to the 'development bureaucrats'. The ideas of intensifying the sustainable development and cohesion have become an inherent part of the EU integration policy. A lack of research, particularly, into the cohesion problems the decisions of which would be associated with HR (Human Resource) practices development (Lobanova, Melnikas2012), as well as insufficient efforts of the dissemination of these ideas in the society can be observed. At the current stage further actualizes problem not only of job creation, but and preservation high level of employee performance and commitment, especially in countries with developing economies.

The aim of this paper is to identify the impact of human resource management practices on employee performance and commitment, using the HRM practices case study in Latvia and Lithuania. To investigate how key employee behavior factors 
like performance and commitment relate to bundles of human resource management practices the expert method was applied, using the crosssectional comparative design of research.

\section{Various approaches to human resource management practices}

Human resource management consists of various practices, and, time passing on, many new practices emerge. According to Guest and Conway (2004) there has been some progress in conceptualising the focus of the HR system, reflected in the growing consensus that a 'high performance' HR system should be designed to ensure that workers possess high skills and competence, a high level of motivation and the opportunity to contribute discretionary effort. An essential statement (hypothesis) of HRM model proposed by Guest (1997) claims that the human resource management practices are an applied art or consistent and smooth way of describing how to combine high normative goals of the organization, employee commitment, high quality, and task flexibility to obtain a higher individual performance. Based on this hypothesis and empirical study (Guest et al., 2000) 18 practices of HRM have been identified, which are considered significant for organization performance (Table 1).

Table 1. The HRM practices which are considered significant for organization performance (source: compiled by authors according to Guest et al. 2000)

\begin{tabular}{|c|l|}
\hline No & The areas of HRM practices by Guest et al. \\
\hline 1 & Realistic job previews \\
\hline 2 & Use of psychometric tests for selection \\
\hline 3 & Well-developed induction training \\
\hline 4 & $\begin{array}{l}\text { Provision of extensive training for } \\
\text { experienced employees }\end{array}$ \\
\hline 5 & Regular appraisals \\
\hline 6 & $\begin{array}{l}\text { Regular feedback on performance from many } \\
\text { sources }\end{array}$ \\
\hline 7 & Individual performance-related pay \\
\hline 8 & Profit-related bonuses \\
\hline 9 & Flexible job descriptions \\
\hline 10 & Multi-skilling \\
\hline 11 & Presence of work-improvement teams \\
\hline 12 & Presence of problem-solving groups \\
\hline 13 & Information provided on firm's business plan \\
\hline 14 & $\begin{array}{l}\text { Information provided on the firm's } \\
\text { performance targets }\end{array}$ \\
\hline 15 & No compulsory redundancies \\
\hline 16 & Avoidance of voluntary redundancies \\
\hline 17 & Commitment to single status \\
\hline 18 & Harmonized holiday entitlement \\
\hline
\end{tabular}

Also the results obtained by other researchers (Purcell et al. 2003; Thompson 2002; West et al. 2002; and others) show, that there is a relationship between the development of HRM practices and organizational performance.

According to Armstrong (2010), the research on the link between HRM and firm performance is helpful, because it confirms the benefits of HRM practices in organizational performance. Version of the HR practices that influence the performance, is following (Table 2).

Table 2. The HR practices that impact on performance (source: compiled by authors according to Armstrong 2010)

\begin{tabular}{|c|l|}
\hline No & \multicolumn{1}{|c|}{ The areas of HRM practices by Armstrong } \\
\hline 1 & Attract, develop and retain high-quality people \\
\hline 2 & Talent management \\
\hline 3 & Learning and development \\
\hline 4 & Manage knowledge and intellectual capital \\
\hline 5 & $\begin{array}{l}\text { Increase engagement, commitment and } \\
\text { motivation }\end{array}$ \\
\hline 6 & Psychological contract \\
\hline 7 & High-performance management \\
\hline 8 & Reward management \\
\hline 9 & Employee relations \\
\hline 10 & $\begin{array}{l}\text { Working environment - core values, leader- } \\
\text { ship, work-life balance, managing diversity, } \\
\text { secure employment }\end{array}$ \\
\hline
\end{tabular}

HR practices, presented by Armstrong (2010), include both some classical areas of HRM practices and new modern trends enhance value of employee's work. It fundamentally confirms that 18 HRM practice areas derived by Guest et al. (2000) can be significant.

Richardson and Thompson (2003) have pointed out that a simple list of different combinations of practices is also inadequate because the specification of interesting strategic choices requires a convincing rationale of how and why a particular combination of practices generates internal and external fit. Also those authors have mean, that Guest and Hoque, for example, were faced with the problem of assigning the firms in their sample to different strategic categories based on whether they had certain combinations of 23 HRM practices; they recognised that some of these practices might be more important than others, but they concluded that 'we know of no theoretical basis on which to determine this', so they treated each of them as equally important (Guest, Hoque 1994; Guest et al. 2000; Guest et al. 2004).

Just in the middle of last decade of XX century MacDuffie observed that every HR practice has a complex role and that 'there is no clear conceptual basis for separating practices affecting motivation from those affecting skill' (MacDuffie 1995). Even 
worse, the motivational impact of many individual HR policies remains to be established. In the period from the middle of last decade of XX century till the end of first decade of XXI century was growing number of studies have complex measures of HR practices. These are often used in multi-variate analyses, which also incorporate background variables like capital/labour ratios, firm size, industrial sector, and so on. But they only rarely include other direct measures of managerial effectiveness. According Richardson and Thompson (2003) this omission might mean that all aspects of managerial effectiveness are being represented just by the HR variables. They have pointed attention, that McMahan et al (1999) provide a very useful conceptual framework for understanding the theoretical perspectives influencing the field, when identify a number of broad theoretical approaches that have influenced empirical work in the area. These they group into 'reactive' theories and 'proactive' theories. The proactive perspectives are: behavioural, transaction costs theory/agency theory, cybernetic systems, resource based view of the firm. The reactive theories they cite are: resource dependence and institutional theory. Authors (McMahan et al. 1999) argue that much of the empirical work in the area is 'data driven theory application' rather than 'theorydriven' research.

David Guest, Jaap Paauwe and Patrick Wright (Guest et al. 2012) in the last new work "HRM and Performance - Achievements and Challenges" have stated that there are many contextual and contingency factors that may shape the HR process at the local level and described some alternative employee-related pathways linking HRM and organizational performance (Fig. 1).

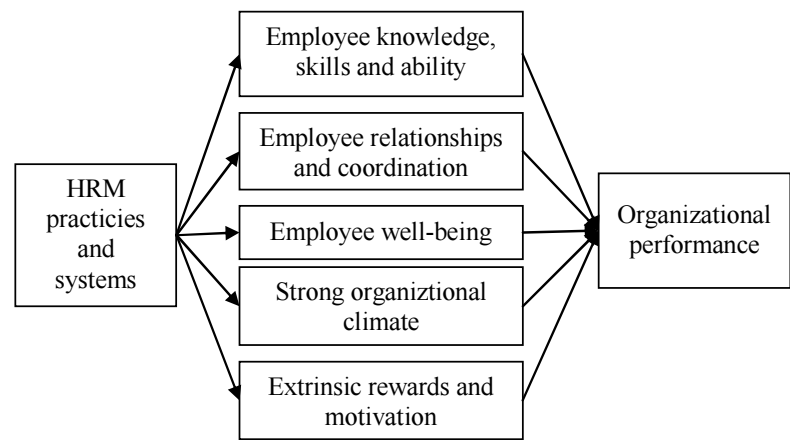

Fig. 1. Some alternative employee-related pathways linking HRM and organizational performance (source: Guest et al 2012)

According Guest et al. (2012) the alternative non-well-being-related pathway of the link between HRM, employee outcomes and organizational performance outlined above, together with the focal well-being-related pathway (Fig. 1). Two points are worth noting about the different pathway: first, the pathways shown are not exhaustive, nor are they mutually exclusive; second, although analytically distinct, the various pathways are not always clearly distinguished in empirical studies of the relationship between HRM and performance.

Indeed, in last decade of XX century some researchers have wondered whether it makes sense at all to think of HRM, well-being and performance in terms of universally valid relationships (Legge 1995; Delery, Doty 1996; cited by Guest et al 2012). The current consensus on the issue appears to be that both universalistic (best practice) and contingency (best fit) approaches are relevant to understanding the HR process in any workplace.

It is worth noting that the linking HRM practices and HRM outcomes framework (Fig. 2) until currently can be considered as an essential concept to identify the impact of HR practices to quality of human resources: employee engagement, because this tends to lead to employee performance and commitment, reduces staff turnover and improves the well-being of employees (Witemeyer 2013; Becker, Cropanzano 2011; Hakanen et al. 2008; Toh et al. 2008; Wright et al. 2007; Michie, West 2004; Wright, Cropanzano 2000).

\begin{tabular}{|c|c|}
\hline $\begin{array}{l}\text { Selection } \\
\text { Socialization } \\
\text { Training and development } \\
\text { Quality Improvement programmes }\end{array}$ & $\begin{array}{l}\text { Skills and } \\
\text { Ability } \\
\text { (Quality) }\end{array}$ \\
\hline $\begin{array}{l}\text { Single status } \\
\text { Job security } \\
\text { Internal promotion } \\
\text { Individualized reward systems }\end{array}$ & $\begin{array}{l}\text { Effort/Motivation } \\
\text { (Commitment) }\end{array}$ \\
\hline $\begin{array}{l}\text { Communication } \\
\text { Employee involvement } \\
\text { Team working } \\
\text { Job design } \\
\text { Flexible job descriptions }\end{array}$ & $\begin{array}{l}\text { Role Structure } \\
\text { and Perception } \\
\text { (Flexibility) }\end{array}$ \\
\hline
\end{tabular}

Fig. 2. Linking HRM practices and HRM outcomes (source: Guest 1997)

According to Kavaliauskienè (Kavaliauskienè 2011), in general an employee's commitment to the organization is perceived as force binding an individual with some particular tasks in a particular organization and appearing through the different forms and dimensions, revealing various reasons that motivate people, provide meaning to their lives and enhance to make a move or to continue it. Kavaliauskiene (2011) means, that the changing nature of the practice in terms of employment and increased opportunities for qualified employees to anchor in job markets acceptable to them have given the concept of an employee's organizational commitment especially much attention from organizational researchers (Martin 2008; Patalano 2008) latterly. 
Employee engagement is a relatively new construct in academic literature and an increasingly popular idea in practice (Witemeyer 2013). Proponents of employee engagement claim a strong positive relationship between engagement and business success, both at the firm and individual levels, and outcomes including retention, productivity, profitability, and customer loyalty and satisfaction. In the absence of consistent conceptualization and measurement, relationships between employee engagement and its antecedents and outcomes cannot be empirically tested. Witemeyer (2013) note, that yet despite popular appeal and numerous academic articles, no consensus exists regarding what employee engagement is or how it should be measured (Marcos, Sridevi 2010, Macey, Schneider 2008; Atridge 2009; Cowardin-Lee, Soyalp 2011; Cho et al. 2006; Standar, Rothmann 2010).

Taking into account that reviewed areas of HR practices and their development trends suggest that scientists in any case, indicate some basic practices of HRM applied by any organization, regardless of its size and scope, the results of the following survey reveal the impact of HRM practice areas in current circumstances in Lithuania and Latvia.

Therefore, the results of the following survey reveal the impact of HRM practice areas in employee commitment and performance in current circumstances of internationalization processes in Lithuania and Latvia.

\section{Investigation of HRM practices impact on employee commitment and performance}

\subsection{Method}

According to Guest, there are 18 most effective HRM practices, which enhance employee's performance and commitment (Guest 2000). To verify Guest's statements the expert method was applied, using the cross-sectional comparative design of research. Two groups of experts - Lithuanian and Latvian - were formed, using the opportunity sampling method. The experts were selected by the criterion of competence in the field of human resource management, i. e. primarily by person's occupational area and the length of experience in the field mentioned above. All appropriate persons were contacted face-to-face or by e-mail and were asked to participate in the current research. As a result, the opinion of 14 Lithuanian experts and 11 Latvian experts was acquired. The expert groups held participants engaged in management of an organisation or a group, personnel management, scientific research work, teaching in institution of higher education, conducting of training courses or seminars, or business consulting. The half of Lithuanian experts and the majority of Latvian experts had occupation in general management or in personnel management (Table 3).

Table 3. Distribution of the number of experts by occupation in general management and personnel management (LT - Lithuanian experts $(\mathrm{n}=14)$; LV - Latvian experts $(\mathrm{n}=11))$

\begin{tabular}{|c|l|c|c|}
\hline No & \multicolumn{1}{|c|}{ Occupational area } & LT & LV \\
\hline 1 & $\begin{array}{l}\text { Management of an organisa- } \\
\text { tion or a group }\end{array}$ & 4 & 5 \\
\hline 2 & Personnel management & 3 & 5 \\
\hline
\end{tabular}

Regarding to experts' experience in the human resource management field, 10 Lithuanian experts and 5 Latvian experts had relevant experience of more than five years (Table 4).

Table 4. Distribution of the number of experts by years of experience in the HRM field (LT - Lithuanian experts $(\mathrm{n}=14)$; LV - Latvian experts $(\mathrm{n}=11))$

\begin{tabular}{|c|l|l|c|}
\hline No & \multicolumn{1}{|c|}{ Years of experience } & LT & LV \\
\hline 1 & 5 and less & 4 & 6 \\
\hline 2 & $6-10$ & 2 & 4 \\
\hline 3 & $11-15$ & 4 & - \\
\hline 4 & $16-20$ & 3 & 1 \\
\hline 5 & 21 and more & 1 & - \\
\hline
\end{tabular}

The expert opinion was clarified with questionnaire that was composed of two main parts. In both parts were listed 18 human resource management practices marked out by David Guest as effective practices to enhance employee commitment and performance (Guest 2000). But, in the first part, the impact of each human resource management practice on the employee's performance was be evaluated, and in the second part, the impact of the same practices on the employee's commitment was be evaluated. The impact of human resource management practices was measured by 4-point scale. Respectively, expert was offered to evaluate whether the specific practice "reduces" $(=1)$, "has not impact" $(=2)$, "increases" $(=3)$ or "greatly increases" $(=4)$ the employee's performance (in the first part of questionnaire) and the employee's commitment (in the second part of questionnaire). According to Guest the all of 18 mentioned above practices are effective, consequently, those should at least "increase" employee's performance and commitment. To determine whether this statement is right, the response options "reduces" and "has not impact" were intentionally included into scale of measurement.

The Cronbach's alpha for the scale "The impact of human resource management practices on the employee's performance" was 0.77 in the group of Lithuanian experts, and 0.71 in the group of Latvian experts. This indicates that this scale has acceptable internal consistency in both groups. 
The Cronbach's alpha for scale "The impact of human resource management practices on the employee's commitment" was similar - 0.78 and 0.72 , respectively. Thus, both scales are sufficiently reliable in both expert groups.

To clarify the experts' view of the impact of human resource management practice, and simultaneously to control the experts' individual answers for consistency, in addition to evaluation of the impact of human resource management practices the expert was asked to choose five most effective practices from 18 , and to rank those.

The statistical measures applied in analysis of the acquired data are summarised in Table 5.

Table 5. Statistical measures applied in the current research

\begin{tabular}{|c|l|l|}
\hline No & \multicolumn{1}{|c|}{ Indicator } & Statistical measure \\
\hline 1 & $\begin{array}{l}\text { Level of agreement } \\
\text { among experts }\end{array}$ & Standard Deviation \\
\hline 2 & $\begin{array}{l}\text { Impact level of HRM } \\
\text { practice }\end{array}$ & $\begin{array}{l}\text { Mean; Median; } \\
\text { Frequency; Mode }\end{array}$ \\
\hline 3 & $\begin{array}{l}\text { Difference between im- } \\
\text { pacts of HRM practices } \\
\text { on performance and } \\
\text { commitment }\end{array}$ & $\begin{array}{l}\text { Wilcoxon Signed } \\
\text { Rank Test }\end{array}$ \\
\hline 4 & $\begin{array}{l}\text { Difference between } \\
\text { scores of LT and LV } \\
\text { expert groups }\end{array}$ & $\begin{array}{l}\text { Mann-Whitney } \\
\text { Test }\end{array}$ \\
\hline
\end{tabular}

\subsection{Results and discussion}

Means (M), medians (Me), and standard deviations (SD) for each human resource management practices using the rating given on the 4-point scale were calculated and are shown in Table 6 and 7. Considering the level of agreement among experts on scale "The impact of human resource management practices on the employee's performance", standard deviations of two subscales in Latvian expert group, and standard deviation of one subscale in Lithuanian expert group were above 1 - "Individual performance-related pay" in Latvian group, and "Commitment to single status" in both groups. Thus, there is a good consensus for the rest subscales. Considering the level of agreement among experts on scale "The impact of human resource management practices on the employee's commitment", standard deviations of six subscales in Latvian expert group, and of two subscales in Lithuanian expert group were above 1 "Individual performance-related pay", "Profitrelated bonuses", "Multi-skilling", "Commitment to single status" in Latvian group, "Avoidance of voluntary redundancies" in Lithuanian group, and "Flexible job descriptions" in both groups. Such results indicate that there is a good consensus for the rest subscales, but comparing with the first scale in overall there is a worse consensus.

Table 6. Means, medians, and standard deviations for scale "The impact of human resource management practices on the employee's performance"

\begin{tabular}{|c|c|c|c|c|c|c|c|}
\hline \multirow{2}{*}{ No } & \multirow{2}{*}{$\begin{array}{c}\text { Subscale } \\
\text { (i.e. human resource management practice) }\end{array}$} & \multicolumn{3}{|c|}{ Latvia } & \multicolumn{3}{|c|}{ Lithuania } \\
\hline & & $\mathrm{M}$ & $\mathrm{Me}$ & SD & $\mathrm{M}$ & $\mathrm{Me}$ & SD \\
\hline 1 & Realistic job previews & 3.27 & 3 & 0.79 & 3.21 & 3 & 0.58 \\
\hline 2 & Use of psychometric tests for selection & 2.55 & 3 & 0.52 & 3.00 & 3 & 0.55 \\
\hline 3 & Well-developed induction training & 3.55 & 4 & 0.52 & 3.36 & 3 & 0.50 \\
\hline 4 & Provision of extensive training for experienced employees & 3.27 & 3 & 0.65 & 3.14 & 3 & 0.53 \\
\hline 5 & Regular appraisals & 3.27 & 3 & 0.79 & 3.07 & 3 & 0.92 \\
\hline 6 & Regular feedback on performance from many sources & 3.55 & 4 & 0.52 & 3.50 & 4 & 0.65 \\
\hline 7 & Individual performance-related pay & 3.36 & 4 & 1.03 & 3.36 & 3 & 0.63 \\
\hline 8 & Profit-related bonuses & 3.55 & 4 & 0.52 & 3.07 & 3 & 0.62 \\
\hline 9 & Flexible job descriptions & 2.18 & 2 & 0.75 & 2.57 & 3 & 0.85 \\
\hline 10 & Multi-skilling & 3.00 & 3 & 0.77 & 3.07 & 3 & 0.62 \\
\hline 11 & Presence of work-improvement teams & 2.55 & 3 & 0.69 & 3.07 & 3 & 0.73 \\
\hline 12 & Presence of problem-solving groups & 2.45 & 3 & 0.93 & 3.43 & 4 & 0.65 \\
\hline 13 & Information provided on firm's business plan & 2.64 & 3 & 0.50 & 2.79 & 3 & 0.58 \\
\hline 14 & Information provided on firm's performance targets & 3.36 & 3 & 0.67 & 3.07 & 3 & 0.73 \\
\hline 15 & No compulsory redundancies & 2.64 & 3 & 0.67 & 2.14 & 2 & 0.86 \\
\hline 16 & Avoidance of voluntary redundancies & 2.91 & 3 & 0.54 & 2.07 & 2 & 0.73 \\
\hline 17 & Commitment to single status & 2.55 & 3 & 1.04 & 1.93 & 2 & 1.07 \\
\hline 18 & Harmonised holiday entitlement & 3.18 & 3 & 0.75 & 2.64 & 2.50 & 0.93 \\
\hline
\end{tabular}


Table 7. Means, medians, and standard deviations for scale "The impact of human resource management practices on the employee's commitment"

\begin{tabular}{|c|l|c|c|c|c|c|c|}
\hline \multirow{2}{*}{ No Subscale } & \multicolumn{3}{|c|}{ Latvia } & \multicolumn{3}{c|}{ Lithuania } \\
\cline { 3 - 8 } & (i.e. human resource management practice) & $\mathrm{M}$ & $\mathrm{Me}$ & $\mathrm{SD}$ & $\mathrm{M}$ & $\mathrm{Me}$ & $\mathrm{SD}$ \\
\hline 1 & Realistic job previews & 3.09 & 3 & 0.70 & 3.14 & 3 & 0.66 \\
\hline 2 & Use of psychometric tests for selection & 2.18 & 2 & 0.60 & 2.57 & 3 & 0.76 \\
\hline 3 & Well-developed induction training & 3.09 & 3 & 0.70 & 2.86 & 3 & 0.95 \\
\hline 4 & Provision of extensive training for experienced employees & 3.27 & 3 & 0.79 & 3.29 & 3 & 0.61 \\
\hline 5 & Regular appraisals & 2.91 & 3 & 0.83 & 2.57 & 3 & 0.76 \\
\hline 6 & Regular feedback on performance from many sources & 3.36 & 3 & 0.50 & 2.93 & 3 & 0.62 \\
\hline 7 & Individual performance-related pay & 3.00 & 3 & 1.10 & 3.50 & 4 & 0.65 \\
\hline 8 & Profit-related bonuses & 3.27 & 4 & 1.01 & 3.50 & 4 & 0.65 \\
\hline 9 & Flexible job descriptions & 2.45 & 3 & 1.13 & 2.79 & 3 & 1.05 \\
\hline 10 & Multi-skilling & 3.00 & 3 & 1.10 & 3.21 & 3 & 0.58 \\
\hline 11 & Presence of work-improvement teams & 3.00 & 3 & 0.89 & 3.00 & 3 & 0.68 \\
\hline 12 & Presence of problem-solving groups & 3.00 & 3 & 0.89 & 3.36 & 3 & 0.63 \\
\hline 13 & Information provided on firm's business plan & 2.73 & 3 & 1.01 & 3.14 & 3 & 0.77 \\
\hline 14 & Information provided on firm's performance targets & 3.27 & 3 & 0.65 & 3.07 & 3 & 0.62 \\
\hline 15 & No compulsory redundancies & 3.27 & 4 & 0.90 & 2.93 & 3 & 0.73 \\
\hline 16 & Avoidance of voluntary redundancies & 3.18 & 3 & 0.87 & 2.79 & 3 & 1.05 \\
\hline 17 & Commitment to single status & 2.91 & 3 & 1.22 & 2.86 & 3 & 0.86 \\
\hline 18 & Harmonised holiday entitlement & 3.64 & 4 & 0.50 & 3.43 & 3 & 0.51 \\
\hline
\end{tabular}

Means of all subscales in two scales were not above 2, except subscale "Commitment to single status" of first scale in Lithuanian group. Mean of this subscale is 1.93 , but it is approximately 2 . This implies that in according to the experts' evaluations there is no human resource management practice, which would have a negative impact on employee's performance or commitment. Nevertheless, there were some subscales, which means did not succeed 2.45. In the first scale, these subscales were "Flexible job descriptions" related to Latvian expert group, and "Commitment to single status", "Avoidance of voluntary redundancies", "No compulsory redundancies" related to Lithuanian expert group. In the second scale, only subscale "Use of psychometric tests for selection" related to Latvian expert group had mean below 2.45. This indicates that experts regarded the mentioned practices as neutral, i.e. which have not positive or negative effects on employee's performance or commitment.

The low scores of "Flexible job descriptions" given by Latvian experts can be explained by assumption that flexibly defined job duties might be treated as unclear. On the one hand, uncertainly defined job duties provide more autonomy to employee, but on the other hand, do not give the define tasks. In situation, when employee is not sufficiently experienced or motivated, or when employee's work is interdependent, the unclear job duties can hinder performance.

In accordance with Lithuanian experts, the employee's performance did not impacted by adherence to single status and staff retention. This point of view can be interpreted by supposition that such human resource management practices might be treated as discouraging the employee's motivation to higher achievements. The adherence to single status can enhance employees' perception of interpersonal justice, but worsen the perception of distributive justice (Colquitt 2001). It not be excluded that employee's motivation towards better performance could be based on getting of unique or higher status. As for staff retention, there are also advantages and drawbacks affecting employee's performance. If employer takes care of staff stability and does not provoke voluntary turnover, this can establish the long-term responsibility of employee on own work results. On the other hand, the firm belief in guaranteed safety can generate impression that it is possible to be lazy.

Evaluating the impact of "use of psychometric tests for selection" on employee's commitment, Latvian experts did not consider this practice as good or bad. Perhaps such consideration follows from experience that selection of appropriate candidate does not ensure loyal employee in future.

Means of most of the human resource management practices in both scales are from 2.45 to 3.45. Thus, Latvian and Lithuanian experts treated the great part of listed practices as positively influenced the employee's performance and commitment. Therefore, this result in overall confirms Guest's statement about effectiveness of these practices.

It is necessary to be noted that there were a few practices with means above 3.45. Latvian experts highly recognised the positive effect of "Well-developed induction training", "Regular feedback on performance from many sources", 
"Profit-related bonuses" on the employee's performance (all these practices had means 3.55). Lithuanian experts also highly rated "Regular feedback on performance from many sources" (mean was 3.50). It is not surprising because objective feedback in time is an essential condition for good performance.

In the second scale, Latvian experts particularly highly rated "Harmonised holiday entitlement" (mean was 3.64), but Lithuanian experts highlighted "Individual performance-related pay" and "Profit-related bonuses" (means of both subscales were 3.50). This suggests that Lithuanian experts confer greater importance of monetary measures in formation of employee's commitment. Whereas Latvian experts believe more in effectiveness of employer's condescension to employee's wishes of own free time.

To verify and precise the experts' evaluation of the impact of human resource management practice on the employee's performance and commitment, the experts' choices of five most effective practices separately for each scale were calculated and summarised. The practices, chosen by $50 \%$ and more of experts as most effective are presented in Figure 3. In addition to counting of experts' choices, means (M) and modes (Mo) of these choices were estimated (Table 8 and 9).

Table 8. Means and modes of HRM practices chosen as most effective for enhancement of employee's performance $(1=$ first rank (the most effective); $5=$ fifth rank)

\begin{tabular}{|c|l|c|c|}
\hline No & \multicolumn{1}{|c|}{ Subscale } & M & Mo \\
\hline 1 & $\begin{array}{l}\text { LV experts' opinion: Individu- } \\
\text { al performance-related pay }\end{array}$ & 1.71 & $1 ; 2$ \\
\hline 2 & Profit-related bonuses & 3.71 & 4 \\
\hline 3 & $\begin{array}{l}\text { Information provided on firm's } \\
\text { performance targets }\end{array}$ & 3.43 & $4 ; 5$ \\
\hline 4 & Regular appraisals & 1.83 & 2 \\
\hline 5 & $\begin{array}{l}\text { Regular feedback on perfor- } \\
\text { mance from many sources }\end{array}$ & 2.50 & 3 \\
\hline 6 & $\begin{array}{l}\text { LT experts' opinion: Well- } \\
\text { developed induction training }\end{array}$ & 2.56 & $1 ; 4$ \\
\hline 7 & $\begin{array}{l}\text { Regular feedback on perfor- } \\
\text { mance from many sources }\end{array}$ & 2.44 & 2 \\
\hline 8 & $\begin{array}{l}\text { Provision of extensive train- } \\
\text { ing for experienced employees }\end{array}$ & 3.50 & 3 \\
\hline 9 & $\begin{array}{l}\text { Individual performance-related } \\
\text { pay }\end{array}$ & 2.75 & $1 ; 3$ \\
\hline
\end{tabular}

Only statistics of those practices, which were selected by $50 \%$ and more of experts, are shown in Tables.

As a result, the leader of most effective practices for enhancement of employee's performance was "Individual performance-related pay", according to Latvian experts, and "Regular feedback on performance from many sources", according to Lithuanian experts.

Table 9. Means and modes of HRM practices chosen as most effective for enhancement of employee's commitment

\begin{tabular}{|c|l|c|c|}
\hline No & \multicolumn{1}{|c|}{ Subscale } & M & Mo \\
\hline 1 & $\begin{array}{l}\text { LV experts' opinion: Profit- } \\
\text { related bonuses }\end{array}$ & 2.50 & 2 \\
\hline 2 & $\begin{array}{l}\text { Harmonised holiday entitle- } \\
\text { ment }\end{array}$ & 3.83 & $4 ; 5$ \\
\hline 3 & $\begin{array}{l}\text { LT experts' opinion: Individ- } \\
\text { ual performance-related pay }\end{array}$ & 1.89 & 1 \\
\hline 4 & Profit-related bonuses & 2.00 & $1 ; 2 ; 3$ \\
\hline 5 & $\begin{array}{l}\text { Provision of extensive train- } \\
\text { ing for experienced employ- } \\
\text { ees }\end{array}$ & 4.29 & $4 ; 5$ \\
\hline 6 & $\begin{array}{l}\text { Harmonised holiday entitle- } \\
\text { ment }\end{array}$ & 3.71 & 2 \\
\hline
\end{tabular}

The results of selection and ranking of five most effective human resource management practices for enhancement of employee's performance in general support the previous results presented in Table 6. In both stages of evaluation, Latvian experts highly assessed "Profit-related bonuses" and "Regular feedback on performance from many sources", and Lithuanian experts highly assessed "Regular feedback on performance from many sources". Besides of this, the selection and ranking of practices revealed the new emphases. In comparison with the average levels of evaluated practices' impacts on employee performance, at next stage of evaluation Latvian experts stressed more the importance of "Individual performance-related pay", "Information provided on firm's performance targets" and "Regular appraisals", while Lithuanian experts stressed more the importance of "Well-developed induction training", "Individual performance-related pay" and "Provision of extensive training for experienced employees". 


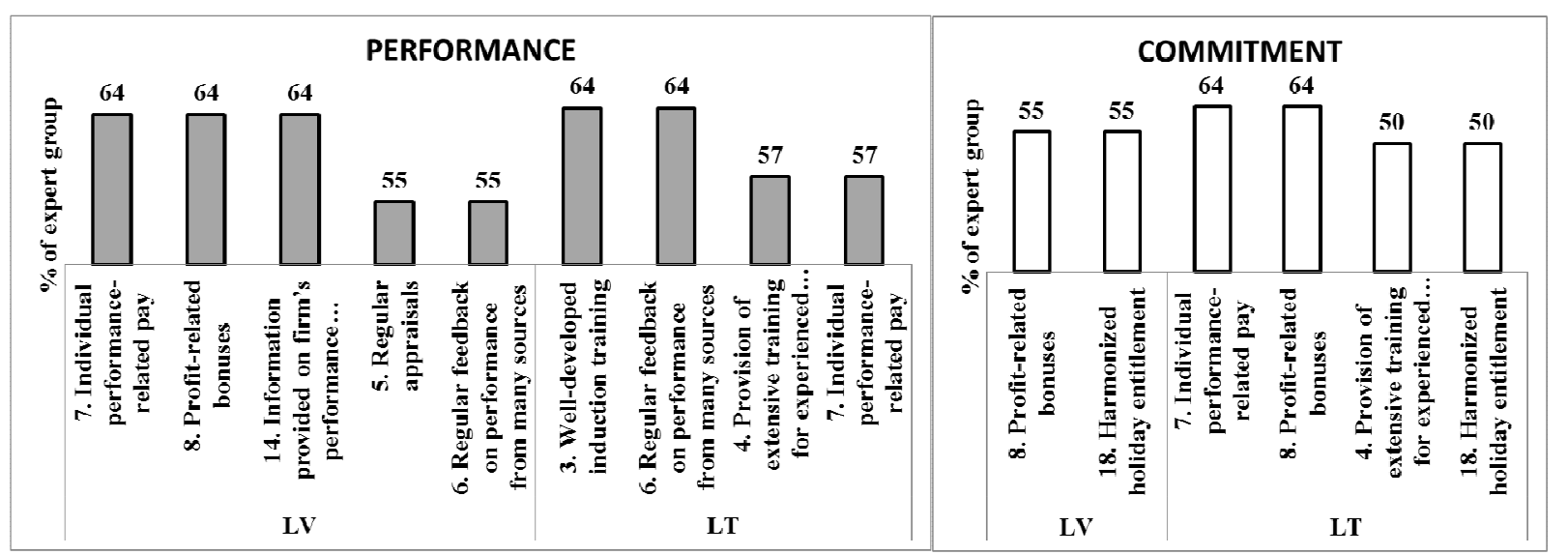

Fig. 3. Results of experts' choices of five most effective HRM practices (LV - Latvian experts, $n=11$; LT - Lithuanian experts, $\mathrm{n}=14$ )

In selection and ranking of five most effective human resource management practices for enhancement of employee's commitment, Latvian experts did not give special preferences to some practices. Nevertheless, relatively higher scores got "Profit-related bonuses" and "Harmonised holiday entitlement". This is consistent with the results presented in Table 7. In both stages of evaluation, Latvian experts highly assessed "Harmonised holiday entitlement", but in second stage, the value of "Profit-related bonuses" on employee's commitment was emphasised.

The results of selection and ranking of most effective practices for enhancement of employee's commitment in Lithuanian expert group, also, reflect the results of previous stage of evaluation. On the top remained "Individual performance-related pay" and "Profit-related bonuses". In addition to this, the importance of "Harmonised holiday entitlement" and "Provision of extensive training for experienced employees" on employee's commitment was more highlighted in this stage of evaluation.

Taking into consideration the results of both stages of expert evaluation it must be concluded that Latvian experts recognised "Profit-related bonuses", and Lithuanian experts "Regular feedback on performance from many sources" as the most effective human resource management practices for enhancement of employee's performance. As for enhancement of employee's commitment, Latvian experts pointed out "Harmonised holiday entitlement", but Lithuanian experts "Individual performance-related pay" and "Profit-related bonuses" as the most effective human resource management practices.

To verify, is there a significant difference between scores of impacts of human resource management practices on performance and commitment, Wilcoxon Signed Rank Test was conducted. Comparing aggregate data of both scales, this sta- tistical test did not support significant difference in results of both Latvian and Lithuanian expert groups (at $p$ less than 0.05 ). This indicates that both scales are similar, and thereby Guest's statement about interchangeable of listed above human resource management practices' effect on employee's performance and commitment is supported. But comparing data of each subscales, Wilcoxon Signed Rank Test revealed significant difference in subscale "No compulsory redundancies" in data set from Latvian experts (Exact Sig. (2-tailed) or $p=0.031$ ), and in subscales "Commitment to single status" $(p=0.008)$, "Harmonised holiday entitlement" $(p=0.008)$, "No compulsory redundancies" ( $p=0.008)$, "Regular feedback on performance from many sources" $(p=0.008)$ and "Avoidance of voluntary redundancies" $(p=$ 0.031 ) in data set from Lithuanian experts. Respectively, these practices, except "Regular feedback on performance from many sources", were treated as more effective for encouragement of employee's commitment than performance. As for "Regular feedback on performance from many sources", Lithuanian experts significantly higher assessed this practice for encouragement of employee's performance. The fact, that five of the 18 subscales revealed the significantly different scores between scales of performance and commitment, allows to assume about potentially different importance of relevant practices to these categories.

The difference of Latvian and Lithuanian experts' evaluations was analysed performing MannWhitney Test. Comparing aggregate data of both expert groups by this statistical test, significant difference was not supported in results of both scales (at $p$ less than 0.05). Performing the same statistical test for each subscales, there also were not observed significant differences, except subscales "Avoidance of voluntary redundancies" $(p=$ 0.008 ) and "Presence of problem-solving groups" 
$(p=0.010)$ in scale "The impact of human resource management practices on the employee's performance". Latvian experts assessed the value of "Avoidance of voluntary redundancies" for employee's performance higher than Lithuanian experts did, while last ones appreciated more "Presence of problem-solving groups". Thus, in general Latvian and Lithuanian experts similar evaluated the impact of human resource management practices on employee's performance and commitment.

\section{Conclusions}

Study of various approaches to human resource management practices show, that at the present stage of internationalization and eurointegration proceses linking HRM practices and HRM outcomes until currently can be considered as an essential concept to identify the impact of HRM practices to quality of human resources: employee performance and commitment, employee engagement, reduces staff turnover and improves the well-being of employees.

The results of expert survey revealed that Latvian experts recognised profit-related bonuses, and Lithuanian experts - regular feedback on performance from many sources as the most effective human resource management practices for encouragement of employee's performance. Whereas harmonised holiday entitlement by Latvian experts' opinion, and individual performance-related pay with profit-related bonuses by Lithuanian experts' opinion are the most effective practices for encouragement of employee's commitment.

Looking to the both scales - "The impact of human resource management practices on the employee's performance" and "on employee's commitment" as a whole, those similarities found out, and therefore it might be supposed that the complete set of analysed practices have analogous effects on employee's performance and commitment. The effects of separate practices on employee's performance and commitment should be explored on a more extensive sample basis in further studies.

In overall, there are not significant differences between Latvian and Lithuanian experts' evaluations of the impact of human resource management practices on employee's performance and commitment.

\section{References}

Armstrong, M. 2010. Armstrong's essential human resource management practice: a guide to people management. Kogan Page.
Attridge, M. 2009. Measuring and Managing Employee Work Engagement: A Review of the Research and Business Literature, Journal of Workplace Behavioral Health 24(4): 383-398.

http://dx.doi.org/10.1080/15555240903188398

Becker, W. J.; Cropanzano, R. 2011. Dynamic aspects of voluntary turnover: an integrated approach to curvilinearity in the performance-turnover relationship, Journal of Applied Psychology 96(2): 233-246. http://dx.doi.org/10.1037/a0021223

Cho, J.; Laschinger, H. K. S.; Wong, C. 2006. Workplace empowerment, work engagement and organizational commitment of new graduate nurses, Canadian Journal of Nursing Leadership 19(3): 43-60. http://dx.doi.org/10.12927/cjnl.2006.18368

Colquitt, J. A. 2001. On the dimensionality of organizational justice: A construct validation of a measure, Journal of Applied Psychology 86(3): 386-400. http://dx.doi.org/10.1037/0021-9010.86.3.386

Cowardin-Lee, N.; Soyalp, N. 2011. Improving organizational workflow with social network analysis and employee engagement constructs, Consulting Psychology Journal: Practice and Research 63(4): 272-283. http://dx.doi.org/10.1037/a0026754

Guest, D. E.; Hoque, K. 1994. The good, the bad and the ugly: employment relations in new non-union workplaces, Human Resource Management Journal 5(1): 1-14. http://dx.doi.org/10.1111/j.17488583.1994.tb00356.x

Guest, D.; Paauwe, J.; Wright, P. (Ed.). 2012. HRM and Performance - Achievements and Challenges, John Wiley \& Sons.

Guest, D. E 2000. Peace by peace [online]. London: CIPD. Available from Internet: http://www.cipd.co.uk/pm/peoplemanagement/b/w eblog/archive/2013/01/29/2163a-2000-07.aspx

Guest, D. E.; Michie, J.; Sheehan, M.; Conway, N.; Metochi, M. 2000. Effective people management: initial findings of future of work survey. London: CIPD.

Guest, D. E. 1997. Human resource management and performance: a review and research agenda, The International Journal of Human Resource Management 8(3): 263-276. http://dx.doi.org/10.1080/095851997341630

Guest, D. E.; Conway, N.; Dewe, P. 2004. Using sequential tree analysis to search for 'bundles' of HR practices, Human Resource Management Journal 14(1): 79-96. http://dx.doi.org/10.1111/j.17488583.2004.tb00113.x

Guest, D. E.; Conway, N. 2004. Employee Well-Being and the Psychological Contract, CIPD, London.

Guest, D. E.; Michie, J.; Sheehan, M.; Conway, N.; Metochi, M. 2000. Effective people management: initial findings of future of work survey, CIPD London.

Hakanen, J. J.; Schaufeli, W.; Ahola, K. 2008. The Job Demands-Resources model: A three-year crosslagged study of burnout, depression, commitment, and work engagement, Work \& Stress 22(3): 224241.

http://dx.doi.org/10.1080/02678370802379432 
Kavaliauskiene, Ž. 2011. Interactions among the dimensions of an employee's organizational commitment and their antecedents. Doctoral dissertation. Kaunas: Vytautas Magnus university.

Lobanova, L.; Ozolina-Ozola, I. 2013. Comparative evaluation of the practical areas of human resource management in Lithuania and Latvia, Procedia Social and Behavioral Sciences 110(2014): 607616. Available from Internet: http://dx.doi.org/10.1016/j.sbspro.2013.12.905

Lobanova, L.; Melnikas, B. 2012. Cohesion in the European Union: new challenges for human resource Management, in The 7th International Scientific Conference „Business and Management 2012", ISI web of science conference proceedings, 2012: 398-407.

MacDuffie, J. P. 1995. Human resource bundles and manufacturing performance: organisational logic and flexible production systems in the world auto industry, Industrial and Labor Relations Review 48(2): 197-221. http://dx.doi.org/10.2307/2524483

Macey, W.; Schneider, B. 2008. Engaged in Engagement: We are delighted we did it, Industrial and Organizational psychology 1(1): 76-83. http://dx.doi.org/10.1111/j.17549434.2007.00016.x

Markos, S.; Sridevi, M. 2010. Employee Engagement: The Key to Improving Performance, International Journal Of Business \& Management 5(12): 89-96.

Martin, S. S. 2008. Relational and economic antecedents of organisational commitment, Personnel Review 36(6): 589-608. http://dx.doi.org/10.1108/00483480810906856

McMahan, G. C.; Virick, M.; Wright, P. 1999. Alternative theoretical perspectives for strategic human resource management revisited: progress, problems and prospects, in Wright, P.; Dyer, L.; Boudreau, J.; Milkovich, G. (eds.) Research in Personnel and Human Resource Management, Greenwich CT: JAI Press (forthcoming).

Michie, S.; West, M. A. 2004. Managing people and performance: an evidence based framework applied to health service organizations, International Journal of Management Reviews 5/6(2): 91-111. http://dx.doi.org/10.1111/j.14608545.2004.00098.x

Patalano, C. 2008. A Study of the Relationship between Generational Group Identification and Organizational Commitment: generation $X$ vs. Generation $Y$. Doctoral dissertation, H.Wayne Huizenga Sch- ool of Business and Entrepreneurship Nova Southeastern University.

Purcell, J.; Kinnie, N.; Hutchinson, S.; Rayton, B.; Swart, J. 2003. Understanding the people and performance link: unlocking the black box. London.

Richardson, R.; Thompson, M. 2003. The Impact of People Management Practices on Business Performance: A literature review. [online]. Institute of Personnel and Development. Available from Internet:

http://www.cipd.co.uk/NR/rdonlyres/7749F172C69F-477E-B993-

FABDA69244F2/0/Impactpeoplemgtliteraturerevi ew.pdf

Schuler, R. S. 2000. The internationalization of human resource Management, Journal of International Management 6: 239-260. http://dx.doi.org/10.1016/S1075-4253(00)00025-9

Stander, M. W.; Rothmann, S. 2010. Psychological Empowerment, Job Insecurity and Employee Engagement, SAJIP: South African Journal Of Industrial Psychology 36(1): 1-8.

Thompson, M. 2002. High Performance Work Organization in UK Aerospace, Society of British Aerospace Companies, London.

Toh, S. M.; Morgeson, F. P.; Campion, M. A. 2008. Human resource configurations, Journal of Applied Psychology 93(4): 864-882. http://dx.doi.org/10.1037/0021-9010.93.4.864

West, M. A.; Borrill, C.; Dawson, J. 2002. The link between the management of employees and patient mortality in acute hospitals, International Journal of Human Resource Management 13(8): 1299_ 1310 . http://dx.doi.org/10.1080/09585190210156521

Witemeyer, H. A. 2013. Employee Engagement Construct and Instrument Validation. Business Administration Dissertations. Georgia State University.

Wright, T. A.; Cropanzano, R.; Bonnet D. G. 2007. The moderating role of employee well-being on the relation between job satisfaction and job performance, Journal of Occupational Health Psychology 12(2): 93-104. http://dx.doi.org/10.1037/1076-8998.12.2.93

Wright, T. A.; Cropanzano, R. 2000. Psychological well-being and job satisfaction as predictors of job performance, Journal of Occupational Health Psychology 5(1): 84-94.

http://dx.doi.org/10.1037/1076-8998.5.1.84 